grounds of religion or belief under the Employment Equality (Religion or Belief) Regulations 2003. The tribunal concluded that she had suffered direct and indirect discrimination and harassment on grounds of religion or belief. She had demonstrated that she had suffered a number of detriments (contrary to Regulation 10(3)), which the tribunal was able to view cumulatively and conclude that there was direct discrimination on grounds of her Christian faith. The requirement that all registrars should carry out civil partnership ceremonies and registration duties constituted indirect discrimination, since this put individuals who held orthodox Christian beliefs about marriage at a disadvantage and actually disadvantaged Miss Ladele, and the council had failed to show that this was a proportionate means of achieving a legitimate aim. The council's refusal to take her views seriously, the allegations that she was discriminating on grounds of sexual orientation and was displaying homophobia, and the fact that she was subjected to disciplinary proceedings constituted harassment. The tribunal noted that the case involved 'a direct conflict between the legislative protection afforded to religion or belief and the legislative protection afforded to sexual orientation'. The tribunal stated that 'Both sets of rights are protected. One set of rights cannot override the other set of rights.' In protecting the rights of the lesbian, gay, bisexual and transsexual community, the council had ignored Miss Ladele's rights in respect of her orthodox Christian beliefs.

This case note was supplied by Frank Cranmer and Russell Sandberg. A fuller version appeared in Law and Justice and is reproduced with permission.

doi:10.1017/So956618X09001835

\title{
Johnston v Liverpool Diocesan Board of Finance
}

Liverpool Employment Tribunal, June 2008

Unfair dismissal - relationship between bishop and employee

The claimant alleged unfair dismissal by the Diocesan Board of Finance (DBF) for which he had been Director of Communications. An essential part of the job was working with the diocesan bishop and the media in relation to publicity. In early 2006, the claimant left his wife and began another relationship. He had canvassed that issue with the bishop. In November 2006, a press release was issued on behalf of the bishop apparently claiming, inter alia, that he had given guidance to the claimant and his new partner and that the claimant's future with the DBF was in jeopardy. The claimant submitted a grievance and a meeting took place in January 2007. The claimant lodged an appeal in March 2007, at which he read out a statement accusing the bishop of lying in the November press 
statement. A disciplinary meeting took place in June 2007 and the claimant was dismissed. He appealed and was reinstated. A 'review meeting' was held in September 2007, which was, in fact, a disciplinary meeting at which the parties discussed the claimant remaining in post. It was concluded that the necessary relationship of trust had broken down between the bishop and the claimant and he was dismissed. The employment tribunal had to decide whether the DBF had acted reasonably in treating the breakdown in the relationship as justification for the claimant's dismissal. The tribunal was concerned that, in June 2007, at a private meeting between a representative of the DBF and the bishop, the bishop had expressed the view that the relationship had broken down and that the claimant's position was untenable. This was never disclosed to the claimant. The tribunal further concluded that the investigation into the allegations against the claimant was inadequate. The main concern had arisen out of the accusation that the bishop was a liar. No steps had been taken to canvass this issue with the bishop. The consequence was that there was no adequate evidence before the DBF's representative upon which he could conclude that the claimant's assertion was untrue. In those circumstances, the tribunal concluded, any reasonable employer would have to proceed on the basis that the claimant was correct and that the bishop had, indeed, lied. A problem had clearly arisen in the relationship between the bishop and the claimant. If the reason for the problem was the fact that the claimant had complained of the wholly improper treatment by the bishop and the DBF had not undertaken sufficient investigation to establish otherwise, the tribunal concluded that the complainant's dismissal was unreasonable. By agreement, a sum of $£ 22,000$ was paid in settlement. [JG]

doi:10.1017/So956618Xo9001847

\section{R (on the application of Baiai) v Secretary of State for the Home Department} House of Lords: Lords Bingham, Rodger, Brown, Neuberger and Baroness Hale, July 2008

Immigration - right to marry - discrimination - human rights

The Secretary of State appealed against a decision that a scheme established under section 19 of the Asylum and Immigration (Treatment of Claimants, etc) Act 2004 involved a disproportionate interference with the respondents' right to marry under Article 12 of the European Convention on Human Rights. Section 19 applied to persons subject to immigration control and to all United Kingdom marriages save for Anglican marriages. The Secretary of State accepted that the distinction between Anglican and civil marriage contained within section 19 was discriminatory and undertook to remove it. Under the terms of section 19, the applicants were required to obtain the written permission of the Secretary of 